\title{
都市再生推進法人によるエリアマネジメントの実態
}

\author{
事業継続性の確保と制度活用に着目して
}

\section{A STUDY OF REALITIES IN THE AREA MANAGEMENT BY URBAN RENEWAL CORPORATIONS}

Focusing on the securing business continuity and the using urban renewal corporation system

\section{伊 藤 孝 紀*，大矢知 良**，三宅航平** \\ Takanori ITO, Ryo OYACHI and Kohei MIYAKE}

\begin{abstract}
The objective of this research is to grasp reality of area managements that operated by 'Urban Renewal Corporations'. Realities in the running, securing continuity and utilizing 'Urban Renewal Corporation' system on operated businesses was surveyed. The results are as follows.

There were 2 types of organization on business running methods; 1 . Which mainly operates 'event' businesses 2 . Which mainly operates 'private facilities used' businesses. There were 2 types of organization on profit structure ; 1 . Which secures profit by operating businesses 2 . Which relies on subsidy. There were 2 types of organization on utilization of ' $U$ rban Renewal Corporation' system. 1 . Which utilizes multiple systems 2. Which does not utilize system.

It is necessary to use 'Urban Renewal Corporation' system on profit businesses, to maintain business continuity on area management operated by 'Urban Renewal Corporation'.
\end{abstract}

Keywords : U rban Renewal Corporation, Area M anagement, Business Contiuity , U sing System 都市再生推進法人，エリアマネジメント，事業継続性，制度活用

\section{1. はじめに}

\section{1. 研究の背景と目的}

我が国が人口減少・超高齢社会の到来を迎え、人口減少に伴う税 収の減少や高齢化に伴う社会保障費の増大などにより、行政の財政 状沉は逼迫しつつあることから、民間による自主的な取組を促進す ることが重要となっている ${ }^{1)}$ 。

また、都市機能の郊外移転により、中心市街地における商機能の 衰退や空き店舗、未利用地の増加に歯止めが掛からない状況であ り、「日本再興戦略」注1) において定められた「コンパクトシティの 実現」注22 に向け、民間投資の喚起を軸とした中心市街地の活性化 を図っている ${ }^{2)}$ 。

そこで、地権者や企業、開発事業者などの民間が主体となって良 好な都市景観および市街地環境の維持・管理、来場者促進のための 駐車場経営、空室率の高いビルや利用率の低い行政所有の空間の利 活用、公共施設および公開空地の活用による防災訓練の実施、にぎ わいを創出するイベントの開催、まちをPRする情報発信などのエリ アマネジメント (以下、エリマネ) が実施されている ${ }^{3)}$ 。

そのようななか、都市再生特別措置法の一部改正 (2011 年 4 月) により、駅前広場や道路空間などの公共空間を活用する規制緩和が 盛り込まれた「都市再生推進法人」制度（以下、法人制度）が創設 された。法人制度とは、民間のまちづくり組織に公的な位置づけを
与え、併せて支援措置を講ずることにより、その積極的な活用を図 る制度である ${ }^{1)}$ 。

まちづくり組織を「都市再生推進法人」（以下、推進法人）に指定 し、「道路占用許可の特例」制度、「都市利便増進協定」制度など を設けることで、民間のまちづくり組織が公共空間を積極的に活用 し、事業を実施することで、安定した事業収益を確保することが期 待されている ${ }^{4)}$ 。さらに、推進法人には、市町村や民間デベロッパー 等では十分に果たすことができない、事業の推進主体としての役割 を果たすことが期待されており、推進法人や市町村、市町村および 民間事業者で構成される市町村都市再生協議会、国が連携して事業 を推進するバックアップ体制が整いつつある ${ }^{1)}$

また、推進法人の指定は市町村長の裁量でおこなうことが可能で あり、推進法人や市町村、国土交通省が指定手順に関わっている ${ }^{1)}$ 。 推進法人の関係手順を図 1 に、推進法人の指定手順を図 2 に示寸。

しかし、多くのまちづくり組織では、事業継続性に問題があり、事 業収益の確保や人材不足の課題が残る。一方で、法人制度により指定 を受けた推進法人は、その他のまちづくり組織と比心゙、実施可能な 事業の幅が広がり、収益を生み出すことで事業継続性を確保してい る。ゆえに、本研究では今後、まちづくりの新たな担い手として大き な役割が期待される推進法人によるエリマネの実態をヒアリング調 查により明らかにし、事業収益の確保や人材、法人制度の活用状況の

\footnotetext{
* 名古屋工業大学大学院工学研究科 准教授 - 博士 (芸術工学)

** 名古屋工業大学大学院工学研究科 博士前期課程 - 学士 (工学)
}

Assoc. Prof., Graduate School of Engineering, Nagoya Institute of Technology, Ph.D.(design)

Master Course Student, Graduate School of Engineering, Nagoya Institute of

Technology, Bachelor of Engineering 
視点から、どの事業に事業継続性があり、運営上の有用性があるか を把握することを目的とする。

\section{2. 都市再生推進法人の設立について}

2014 年 7 月時に推進法人に指定された 15 組織の沿革をみるために、 組織名称・組織法人格の種類、組織設立年、推進法人指定年、設立 から指定までの期間、活動地区、雇用者の総数と共に、推進法人の 指定推移を図 3 に示寸。

図 3 より、設立年をみると 1990 年以前は、駅前ビルの管理会社と して T09 牛久都市開発株式会社 (以下、T09 牛久) が、柏市総合開 発計画の推進上必要とされる土地の取得や造成などをおこなう会社 として T11一般財団法人柏市まちづくり公社（以下、T11 柏公社） が設立された。

1990 年後半 -2000 年前半は、地元の民間企業と行政が協働して設 立し、事業を実施する第三セクター ${ }^{i \ddagger 4)}$ として T02 株式会社まちづくり とやま（以下、T02 とやま）や T05 株式会社飯田まちづくりカンパニー (以下、T05 飯田)、T06 まちづくり福井株式会社 (以下、T06 福井)、 T08 秋葉原タウンマネジメント株式会社 (以下、T08 秋葉原)、T12 一般財団法人柏市みどりの基金 (以下、 $\mathrm{T} 12$ 柏みどり)、が設立された。 また、保険・医療・福祉事業を実施する NP O 法人が多いなか ${ }^{5)}$ 、こ の時期からまちづくりを実施する NP 0 法人が増加しはじめ、T03NP0

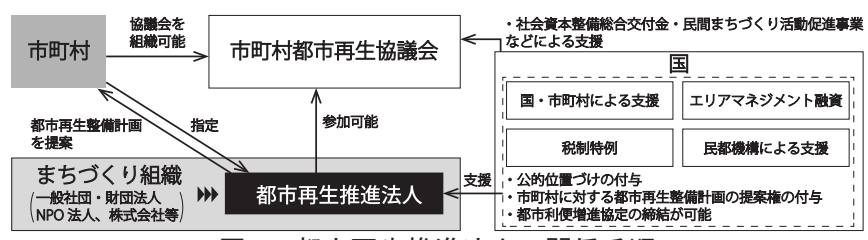

図 1 都市再生推進法人の関係手順

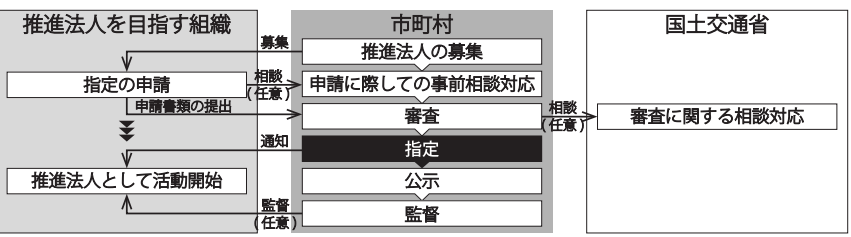

図 2 都市再生推進法人の指定手順
法人南信州おひさま進歩 ( 以下、T03 南信州 ) や T04NP0 法人いいだ 応援ネットイデア (以下、T04いいだイデア) が同時期に設立された。 2000 年後半 -2010 年前半は、駅前や郊外に都市機能が集約され、 衰退が進む中心市街地の活性化を担うまちづくり組織として T01 札 幌大通まちづくり株式会社 (以下、T01 札幌) や T14 株式会社まち づくり川越（以下、T14 川越）、T15 草津まちづくり株式会社（以下、 T15 草津）が、駅前再開発に伴う駅前および周辺地区の活性化を担 うまちづくり組織として T07一般社団法人大手町・丸の内・有楽町 地区まちづくり協議会 (以下、T07 大丸有) や T10一般社団法人柏 の葉アーバンデザインセンター ( 以下、T10 柏の葉)、T13 一般社団 法人グランフロント大阪 TMO （以下、T13 大阪）が設立された。以上 より、各推進法人によって設立年や設立経緯が異なることがわかる。 また、推進法人は、駅前および周辺地区、中心市街地などにおいて、 地域の問題点を解決し、貢献することを目指した事業を実施している。

\section{3. 先行研究と本研究の位置づけ}

まちづくり組織によるエリマネの実態に関する先行研究をみる と、エリマネの実態を地区特性別に分類・比較する視点からは浅井 ら ${ }^{6)}$ による研究があげられる。これは、大都市都心部におけるエリ マネの全体像を捉え、地区別に類型化することで、まちづくり組織 のあり方とその活動内容を明らかにしている。しかし、事業継続性 の確保やまちづくりに関する制度活用などの視点からの考察はみら れない。

法人制度導入の視点からは芦野ら ${ }^{7)}$ にる研究があげられる。こ れは、ケーススタディを通して民間によるまちづくり組織が法人設 立を検討する際に必要な要件やその支援策について明らかにしてい る。しかし、設立時における法人制度導入に関する研究であり、設 立後に実施する事業における法人制度活用などの視点からの考察は みられない。

法人制度活用による事業継続性の確保の視点からは泉山ら ${ }^{8)}$ によ る研究があげられる。これは、ヒアリング調查により、法人制度の メリットおよび法人制度を活用した事業を明らかにし、さらに法人 制度が行政用地にて実施する事業で活用しや寸い一方で、公共空間

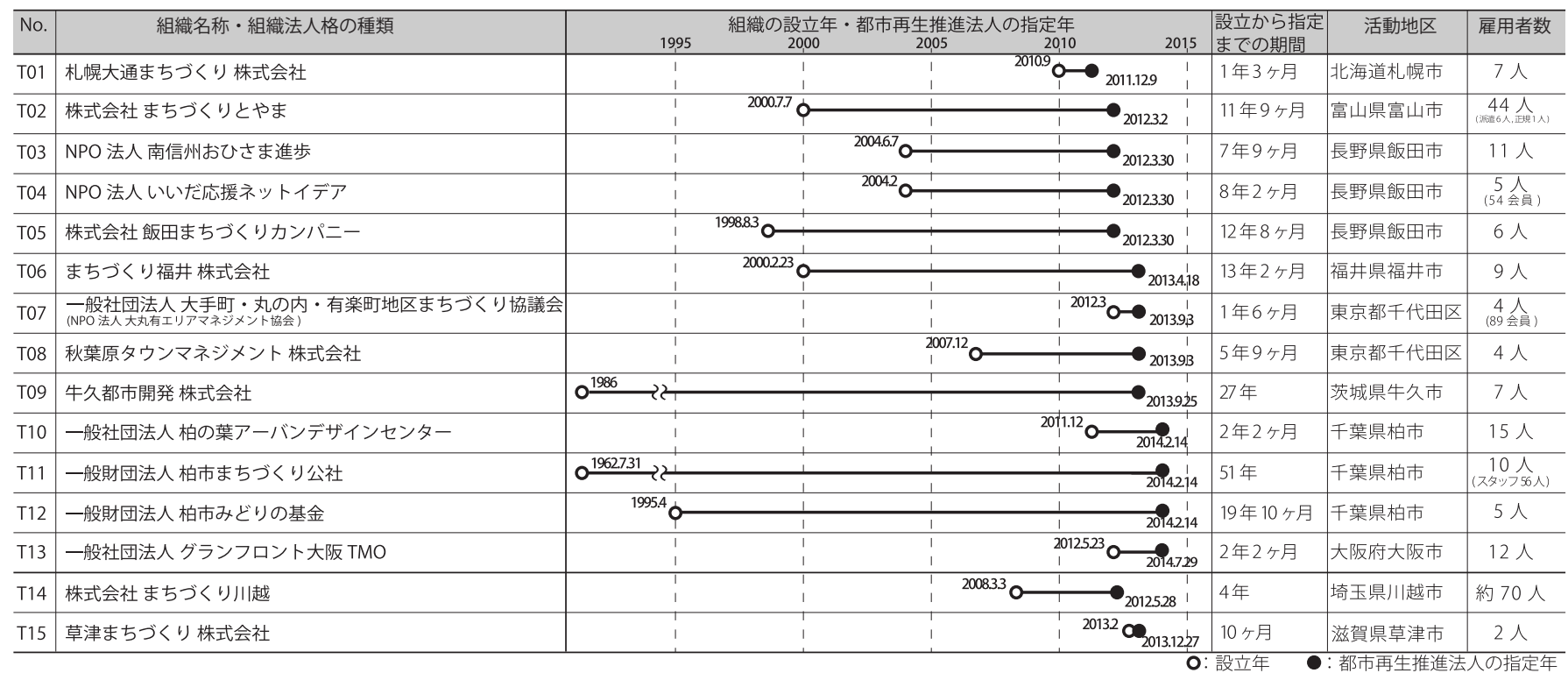

図 3 都市再生推進法人の指定推移 
表 1 本研究の調査手順

\begin{tabular}{|c|c|c|c|}
\hline 段階 & 調査名 & 期間 & 内容 \\
\hline (1) & 文献調査 & $\begin{array}{l}2014 \text { 年 } 7 \text { 月 } \\
-2015 \text { 年 } 8 \text { 月 }\end{array}$ & $\begin{array}{l}\text { 推進法人の公開されている情報や報告書など } \\
\text { から実施事業及びエリマネの沿革を把握。 }\end{array}$ \\
\hline (2) & ヒアリング調査 $[$ メール $]$ & 2015 年 9 月 & $\begin{array}{l}\text { 実施事業の有無や事業の継続年数、収益構成 } \\
\text { 比、担当者数を把握。 }\end{array}$ \\
\hline (3) & ヒアリング調査 [ 面会 ] & $\begin{array}{r}2015 \text { 年 } 10 \text { 月 } \\
-11 \text { 月 }\end{array}$ & $\begin{array}{l}\text { 法人制度の活用経緯、組織の運用スキームを } \\
\text { 把握。 }\end{array}$ \\
\hline
\end{tabular}

にて実施する事業で活用するハードルの高さを明らかにしている。 この研究は、法人制度創設 1 年目におこなわれたものであり、指定 組織も 6 組織であった。本研究では、調査開始時 (2014 年 7 月) に 15 組織に増えていることから、事業継続性の確保および法人制度活 用による事業の全体像を把握することが可能である。

そのため、本研究をおこなうことは、事業継続性の確保および法 人制度活用から、推進法人によるエリマネの実態を明らかにしよう とする点で意義があるといえる。

\section{4. 調査概要}

本研究は 3 段階の調査を実施し、推進法人によるエリマネの実態 を明らかにした。本研究の調查手順を表 1 に示す。

調査対象として、調査開始時 (2014 年 7 月) に推進法人に指定さ れていた 15 組織のうち、段階(1)から(3)の一連の調査が可能であった 注5) 13 組織（T01-T13）を選定した。

本調查は、(1)文献調查を 2014 年 7 月 -2015 年 8 月まで実施するこ とで、各推進法人の公開されている情報や報告書などから実施事業 やエリマネの沿革を把握し、(2)ヒアリング調査 [メール ] を2015 年 9 月の期間に約 2 週間の回答期間で実施することで、各実施事業の 継続年数や年間収益に対する事業収益の構成比 (以下、収益構成比注 ${ }^{6)}$ ) 、担当者数を回答してもらい、(3)ヒアリング調査 [面会 ] を 2015 年 10 月 -11 月の期間に約 2 時間の面会形式で実施することで、法人 制度の活用経緯や組織の運用スキームを回答してもらった。

\section{2. 実施事業からみるエリアマネジメントの実態}

\section{1. 都市再生推進法人の基本情報と指定について}

推進法人の基本情報と指定について整理する。図 3 より、組織法 人格の種類、活動地区、雇用者数をみると、T01 札幌は北海道札幌 市で活動している株式会社であり、雇用者の総数は 7 人である。

表 2 実施事業の把握に用いたアイテムとカテゴリー

\begin{tabular}{|c|c|c|c|}
\hline アイテム & カテゴリー & & \\
\hline Aイベント & $\begin{array}{l}\text { A1 マルシェ } \\
\text { A4 文化 } \\
\text { A7 セミナー・シンポジウム }\end{array}$ & $\begin{array}{l}\text { A2 歩行者天国 } \\
\text { A5 教育 } \\
\text { A8 オープンカフェ }\end{array}$ & $\begin{array}{l}\text { A3 芸術 } \\
\text { A6 物販·飲食事業 } \\
\text { A9 アクティイ゙ティ·交流 }\end{array}$ \\
\hline B 情報発信 & $\begin{array}{l}\text { B1 情報発信拠点 } \\
\text { B4 サイン・地図 }\end{array}$ & $\begin{array}{l}\text { B2 広告事業 } \\
\text { B5 調査 }\end{array}$ & B3 地域案内 \\
\hline C 防災防犯環境 & $\begin{array}{l}\text { C1 防災·防犯活動 } \\
\text { C4 駐車·駐輪対策 }\end{array}$ & C2 美観形成·緑化 & C3 美化·清掃 \\
\hline D公共施設管理 & D1 指定管理 & D2 指定管理以外 (任意管理 & \\
\hline E民間施設の利用 & $\begin{array}{l}\text { E1 駐車場共通化事業 } \\
\text { E4 空き店舗対策(家守) } \\
\text { E7 コミサイイレンンタサイクル } \\
\text { E10 交流スペースの整備·運裳 }\end{array}$ & $\begin{array}{l}\text { E2 ビル管理共同化事業 } \\
\text { E5 不動産事業(開発·管理) } \\
\text { E8 エネルルギー } \\
\text { S }\end{array}$ & $\begin{array}{l}\text { E3 テナントリーシング事業 } \\
\text { E6 コミュニティバス } \\
\text { E9 エリア共同販促 }\end{array}$ \\
\hline
\end{tabular}

T02 とやまは富山県富山市で活動している株式会社であり、雇用 者の総数は 44 人である。

T03 南信州、T04いいだイデア、T05 飯田は長野県飯田市で連携を 取りながら活動している NPO 法人と株式会社であり、雇用者の総数 はT03 南信州が 11 人、T04いいだイデアが 5 人、T 05 飯田が 6 人である。

T06 福井は福井県福井市で活動する株式会社であり、雇用者の総 数が 9 人である。

T07 大丸有は東京都千代田区で活動する一般社団法人であり、雇 用者の総数は 4 人である。

T08 秋葉原は東京都千代田区で活動する株式会社であり、雇用者の 総数は 4 人である。

T09 牛久は茨城県牛久市で活動する株式会社であり、雇用者の総 数は 7 人である。

$\mathrm{T} 10$ 柏の葉、T11 柏公社、T12 柏みどりは千葉県柏市で連携を取り ながら活動している一般社団法人であり、雇用者の総数は T10 柏の 葉が 15 人、 $\mathrm{T} 11$ 柏公社が 10 人、 $\mathrm{T} 12$ 柏みどりが 5 人である。

$\mathrm{T} 13$ 大阪は大阪府大阪市で活動する一般社団法人であり、雇用者の 総数は 12 人である。

T14川越は埼玉県川越市で活動する株式会社であり、雇用者の総 数は約 70 人である。

$\mathrm{T} 15$ 草津は滋賀県草津市で活動する株式会社で雇用者の総数は 2 人である。

一方で、推進法人の指定年をみると、2011 年 12 月 9 日の T01 札 幌を指定第一号に、2012 年は、長野県飯田市の公募により同時に指 定された T03 南信州、T04 いいだイデア、T05 飯田をはじめ、T06 福井、 T14川越の 5 組織が指定された。2013 年は、千代田区が同時に指定 した T07 大丸有、T08 秋葉原をはじめ、T06 福井、T09 牛久、T15 草 津の 5 組織が指定された。2014 年は、柏市が同時に指定した T10 柏 の葉、 $\mathrm{T} 11$ 柏公社、 $\mathrm{T} 12$ 柏みどりをはじめ、 $\mathrm{T} 13$ 大阪の 4 組織が指定 された。以上より、毎年 4-5 の推進法人が指定されており、都市再 生特別措置法の改正 (2011 年 4 月) から指定数が安定して増加して いることがわかる。

\section{2. 実施事業の指標設定}

推進法人の実施事業を明らかにし、エリマネの実態を把握するた

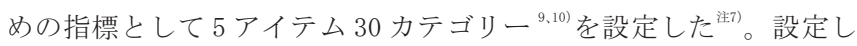
たアイテムとカテゴリーを表 2 に、調查が可能であった 13 組織の各 推進法人による実施事業を表 3 に示す。アイテムとカテゴリーの内 容は以下の通りである。

「Aイベント」はまちのにぎわい創出を目的とした事業であり、「A1 マルシェ」「A2 歩行者天国」「A3 芸術」などの事業をさす。「B 情報 発信」はまちの魅力・価值を発信することを目的とした事業であり、 $「 \mathrm{~B} 1$ 情報発信拠点」「B2 広告事業」「B3 地域案内」などの事業をさ

表 3 各都市再生推進法人による実施事業

\begin{tabular}{|c|c|c|c|c|c|c|c|c|c|c|c|c|c|c|c|c|c|c|c|c|c|c|c|c|c|c|}
\hline \multirow[b]{2}{*}{ アイテム } & \multicolumn{2}{|c|}{$\begin{array}{l}\text { T01 } \\
\text { 札幌 }\end{array}$} & \multicolumn{2}{|c|}{$\begin{array}{c}\text { T02 } \\
\text { とやま }\end{array}$} & \multicolumn{2}{|c|}{$\begin{array}{c}\text { T03 } \\
\text { 南信州 }\end{array}$} & \multicolumn{2}{|c|}{$\begin{array}{c}\text { T04 } \\
\text { いいだイデア }\end{array}$} & \multicolumn{2}{|c|}{$\begin{array}{c}\text { T05 } \\
\text { 飯田 }\end{array}$} & \multicolumn{2}{|c|}{$\begin{array}{c}\text { T06 } \\
\text { 福井 }\end{array}$} & \multicolumn{2}{|c|}{$\begin{array}{c}\text { T07 } \\
\text { 大丸有 }\end{array}$} & \multicolumn{2}{|c|}{$\begin{array}{c}\text { T08 } \\
\text { 秋葉原 }\end{array}$} & \multicolumn{2}{|c|}{$\begin{array}{l}\text { T09 } \\
\text { 牛久 }\end{array}$} & \multicolumn{2}{|c|}{$\begin{array}{c}\mathrm{T} 10 \\
\text { 柏の葉 }\end{array}$} & \multicolumn{2}{|c|}{$\begin{array}{c}\mathrm{T} 11 \\
\text { 柏公社 }\end{array}$} & \multicolumn{2}{|c|}{$\begin{array}{c}\mathrm{T} 12 \\
\text { 柏みどり }\end{array}$} & \multicolumn{2}{|c|}{$\begin{array}{l}\mathrm{T} 13 \\
\text { 大阪 }\end{array}$} \\
\hline & $\begin{array}{l}\text { 球 } \\
\text { 数 }\end{array}$ & $\begin{array}{l}\text { 構 } \\
\text { 筬 }\end{array}$ & $\begin{array}{l}\text { 弿 } \\
\text { 施 } \\
\text { 数 }\end{array}$ & $\begin{array}{l}\text { 構 } \\
\text { 荗 }\end{array}$ & $\begin{array}{l}\text { 塞 } \\
\text { 数 }\end{array}$ & $\begin{array}{l}\text { 構 } \\
\text { 荗 }\end{array}$ & $\begin{array}{l}\text { 害 } \\
\text { 施 } \\
\text { 数 }\end{array}$ & $\begin{array}{l}\text { 構 } \\
\text { 成 }\end{array}$ & $\begin{array}{l}\text { 球 } \\
\text { 数 }\end{array}$ & $\begin{array}{l}\text { 構 } \\
\text { 成 }\end{array}$ & $\begin{array}{l}\text { 塞 } \\
\text { 数 }\end{array}$ & $\begin{array}{l}\text { 構 } \\
\text { 比 }\end{array}$ & $\begin{array}{l}\text { 救 } \\
\text { 数 }\end{array}$ & $\begin{array}{l}\text { 構 } \\
\text { 比 }\end{array}$ & $\begin{array}{l}\text { 塞 } \\
\text { 施 } \\
\text { 数 }\end{array}$ & $\begin{array}{l}\text { 構 } \\
\text { 比 }\end{array}$ & $\begin{array}{l}\text { 塞 } \\
\text { 数 }\end{array}$ & $\begin{array}{l}\text { 構 } \\
\text { 荗 }\end{array}$ & $\begin{array}{l}\text { 䨈 } \\
\text { 数 }\end{array}$ & $\begin{array}{l}\text { 構 } \\
\text { 比 } \\
\text { 比 }\end{array}$ & $\begin{array}{l}\text { 実 } \\
\text { 施 } \\
\text { 数 }\end{array}$ & $\begin{array}{l}\text { 構 } \\
\text { 比 }\end{array}$ & $\begin{array}{l}\text { 実 } \\
\text { 施 } \\
\text { 数 }\end{array}$ & $\begin{array}{l}\text { 構 } \\
\text { 比 }\end{array}$ & $\begin{array}{l}\text { 塞 } \\
\text { 矮 } \\
\text { 数 }\end{array}$ & $\begin{array}{l}\text { 構 } \\
\text { 比 }\end{array}$ \\
\hline Aイベント & 6 & $40.0 \%$ & 5 & $29.4 \%$ & 3 & $50.0 \%$ & 4 & $80.0 \%$ & 5 & $45.5 \%$ & 3 & $27.3 \%$ & 5 & $50.0 \%$ & 4 & $33.3 \%$ & 2 & $28.6 \%$ & 3 & $33.3 \%$ & 4 & $28.6 \%$ & 6 & $42.9 \%$ & 3 & $27.3 \%$ \\
\hline B情報発信 & 2 & $13.3 \%$ & 3 & $17.6 \%$ & 0 & $0 \%$ & 1 & $20.0 \%$ & 0 & $0 \%$ & 3 & $27.3 \%$ & 2 & $20.0 \%$ & 3 & $25.0 \%$ & 0 & $0 \%$ & 3 & $33.3 \%$ & 2 & $14.3 \%$ & 1 & $7.1 \%$ & 2 & $18.2 \%$ \\
\hline C防災防犯環境 & 2 & $13.3 \%$ & 1 & $5.9 \%$ & 1 & $16.7 \%$ & 0 & $0 \%$ & 1 & $9.1 \%$ & 0 & $0 \%$ & 1 & $10.0 \%$ & 3 & $25.0 \%$ & 1 & $14.3 \%$ & 1 & $11.1 \%$ & 3 & $21.4 \%$ & 3 & $21.4 \%$ & 2 & $18.2 \%$ \\
\hline D公共施設管理 & 0 & $0 \%$ & 1 & $5.9 \%$ & 1 & $16.7 \%$ & 0 & $0 \%$ & 0 & $0 \%$ & 2 & $18.2 \%$ & 0 & $0 \%$ & 1 & $8.3 \%$ & 2 & $28.6 \%$ & 0 & $0 \%$ & 1 & $7.1 \%$ & 2 & $14.3 \%$ & 0 & 0 \\
\hline E民間施設の利用 & 5 & $33.3 \%$ & 7 & $41.2 \%$ & 1 & $16.7 \%$ & 0 & $0 \%$ & 5 & $45.5 \%$ & 3 & $27.3 \%$ & 2 & $20.0 \%$ & 1 & $8.3 \%$ & 2 & $28.6 \%$ & 2 & $22.2 \%$ & 4 & $28.6 \%$ & 2 & $14.3 \%$ & 4 & $36.4 \%$ \\
\hline
\end{tabular}


す。「C 防災・防犯、環境維持」（以下、「C 防災防犯環境」）はま ちの安全・安心、美観保全を目的とした事業であり、「C1 防災・防 犯活動」「C2 美観形成・緑化」「C 3 美化・清掃」などの事業をさす。 「D 公共施設管理」は公共施設を活用した事業であり、「D1 指定管理」 $「 \mathrm{D} 2$ 指定管理以外 (任意管理等)」の事業をさす。「E民間施設の公 的利用による地域の魅力・価值、利便の増進」（以下、「E民間施 設の利用」）は民間施設を活用した事業であり、「E1 駐車場共通化 事業」「E2 ビル管理共同化事業」「E3 テナントリーシング事業」な どの事業をさす。

表 3 より、各推進法人による事業実施数と構成比をみていく。T01 札幌は計 15 件の事業を実施しており、「A イベント」は 6 件の $40.0 \%$ と最も高い。また、「E民間施設の利用」は 5 件の $33.3 \%$ 、B 情報発信」「C 防災防犯環境」はそれぞれ 2 件の $13.3 \%$ と事業を実施している一方で、 「D 公共施設管理」は実施していない。

T02 とやまは計 17 件の事業を実施しており、「E民間施設の利用」 は 7 件の $41.2 \%$ と最も高い。また、「A イベント」は 5 件の $29.4 \%$ 、「B 情報発信」は 3 件の $17.6 \%$ 、「C 防災防犯環境」「D 公共施設管理」は それぞれ 1 件の $5.9 \%$ と事業を均質に実施している。

T03 南信州は計 6 件の事業を実施しており、「Aイベント」は 3 件 の $50.0 \%$ と過半を占める。また、「C 防災防犯環境」「D 公共施設管理」 「E民間施設の利用」はそれぞれ 1 件の $16.7 \%$ と実施している一方で、 「В 情報発信」は実施していない。

T04いいだイデアは計 5 件の事業を実施しており、「Aイベント」 は 4 件の $80.0 \%$ と特化した事業である。また、「B 情報発信」は 1 件 の $20.0 \%$ と実施している一方で、「C 防災防犯環境」「D 公共施設管理」 「E 民間施設の利用」は実施していない。

$\mathrm{T} 05$ 飯田は計 11 件の事業を実施しており、「Aイベント」「E民間 施設の利用」はそれぞれ 5 件の $45.5 \%$ と特化した事業である。また、 「C 防災防犯環境」は 1 件の $9.1 \%$ と実施している一方で、 「B 情報発信」 「D 公共施設管理」は実施していない。

T06 福井は計 11 件の事業を実施しており、「Aイベント」「B情報発信」 「E民間施設の利用」はそれぞれ 3 件の 27.3\%、「D 公共施設管理」は 2 件の $18.2 \%$ と事業を均質に実施している一方で、「C 防災防犯環境」 は実施していない。

T07 大丸有は計 10 件の事業を実施しており、「A イベント」は 5 件 の $50.0 \%$ と過半を占める。また、「B 情報発信」「E 民間施設の利用」 はそれぞれ 2 件の $20.0 \%$ 、「C防災防犯環境」は 1 件の $10.0 \%$ と実施 している一方で、「D 公共施設管理」は実施していない。

$\mathrm{T} 08$ 秋葉原は計 12 件の事業を実施しており、「Aイベント」は 4 件 の $33.3 \%$ と最も高い。また、「B 情報発信」「C 防災防犯環境」はそれ ぞれ 3 件の $25.0 \%$ 、「D 公共施設管理」「E 民間施設の利用」はそれぞ れ 1 件の $8.3 \%$ と事業を均質に実施している。

$\mathrm{T} 09$ 牛久は計 7 件の事業を実施している。「A イベント」「D 公共施 設管理」「E民間施設の利用」はそれぞれ 2 件の $28.6 \%$ 、C 防災防犯 環境」は 1 件の $14.3 \%$ と事業を均質に実施している一方で、「B 情報 発信」は実施していない。

$\mathrm{T} 10$ 柏の葉は計 9 件の事業を実施しており、「Aイベント」「B 情 報発信」はそれぞれ 3 件の $33.3 \%$ 、「E民間施設の利用」は 2 件の $22.2 \%$ 、「 防災防犯環境」は1件の $11.1 \%$ と事業を均質に実施して いる一方で、「D公共施設管理」は実施していない。
$\mathrm{T} 11$ 柏公社は計 14 件の事業を実施しており、「Aイベント」「E民 間施設の利用」はそれぞれ 4 件の $28.6 \%$ 、「C 防災防犯環境」は 3 件 の $21.4 \%$ 、「B 情報発信」は 2 件の $14.3 \%$ 、「D 公共施設管理」は 1 件 の $7.1 \%$ と事業を均質に実施している。

$\mathrm{T} 12$ 柏みどりは計 14 件の事業を実施しており、「Aイベント」は 6 件の $42.9 \%$ と最も高い。また、「C 防災防犯環境」は 3 件の $21.4 \% 、 「 D$ 公共施設管理」「E 民間施設の利用」はそれぞれ 2 件の $14.3 \%$ 、 報発信」は 1 件の $7.1 \%$ と事業を均質に実施している。

$\mathrm{T} 13$ 大阪は計 11 件の事業を実施しており、「E民間施設の利用」は 4 件の $36.4 \%$ と最も高い。また、「A イベント」は 3 件の $27.3 \%$ 、「B 情報発信」「C 防災防犯環境」はそれぞれ 2 件の $18.2 \%$ と事業を均質 に実施している一方で、「D 公共施設管理」は実施していない。

以上より、各推進法人はエリマネとして、イベントや景観形成・ 緑化、来場者促進のための駐車場経営、空室率の高いビルの管理 といった、地域の問題点を解決し、貢献する事業を実施している ことがわかる。また、推進法人はエリマネを実施する際、事業収 益の高い事業で得た収益を、賑わい創出や公共還元事業の費用に 充当している。

\section{3. 各都市再生推進法人による実施事業の特徵について}

各推進法人による実施事業の特徵やその継続年数、担当者数をみ ていく。各推進法人による実施事業の継続年数および推進法人指定 後の活動年数、担当者数 ${ }^{\text {i.8) }}$ の集計結果を図 4 亿示す。

図 4 より、T01 札幌は「A イベント」を 6 件、「E民間施設の利用」 を 5 件実施している点が特徴である。「A1 マルシェ」「A2 歩行者天国」 は株式会社として設立する前から地元と連携して 15 年継続してお り、担当者数が 1 人である。「E7 コミサイ・レンタサイクル」は社 会実験による事業検証をおこない、その後、推進法人の指定に伴い 本格的に事業運用する際に、地元コンサルと連携して 7 年継続して いる事業であり、担当者数が 1 人である。

T02 とやまは「D 公共施設管理」を 1 件、「E 民間施設の利用」を 7 件実施している点が特徴である。「D1 指定管理」は中心市街地の再 開発において設置された半屋外広場のにぎわい創出および維持管理 事業として 8 年継続しており、担当者数は 3 人以上である。「E1 駐 車場共通化事業」は来街者増加を目的に商店街組合や各駐車場と連 携して駐車場を無料開放する事業として 10 年継続しており、担当者 数は 1 人である。

T03 南信州は「A イベント」を 3 件、「D 公共施設管理」を 1 件実 施している点が特徵である。「A7セミナー・シンポジウム」は活動 方針である地球温暖化防止の啓発事業として 8 年継続しており、担 当者数は 2 人である。「D1 指定管理」は環境省の推進事業 ${ }^{\text {i99 }}$ におい て設置されたモデルハウスの維持管理をする事業として 8 年継続し ており、担当者数は 2 人である。

T04いいだイデアは「Aイベント」を 4 件実施している点が特徴 である。「A1 マルシェ」はフィギュアを題材にすることで市外から 多くの来訪者を集める事業として 9 年継続しており、担当者数は 1 人である。

$\mathrm{T} 05$ 飯田は「E 民間施設の利用」を 4 件実施している点が特徵であ る。「E1 駐車場共通化事業」「E3 テナントリーシング事業」「E5 不動 産事業 (開発・管理)」は設立当初に中心市街地活性化を目的とし て実施された再開発事業として 14 年継続しており、担当者数は 3 人 


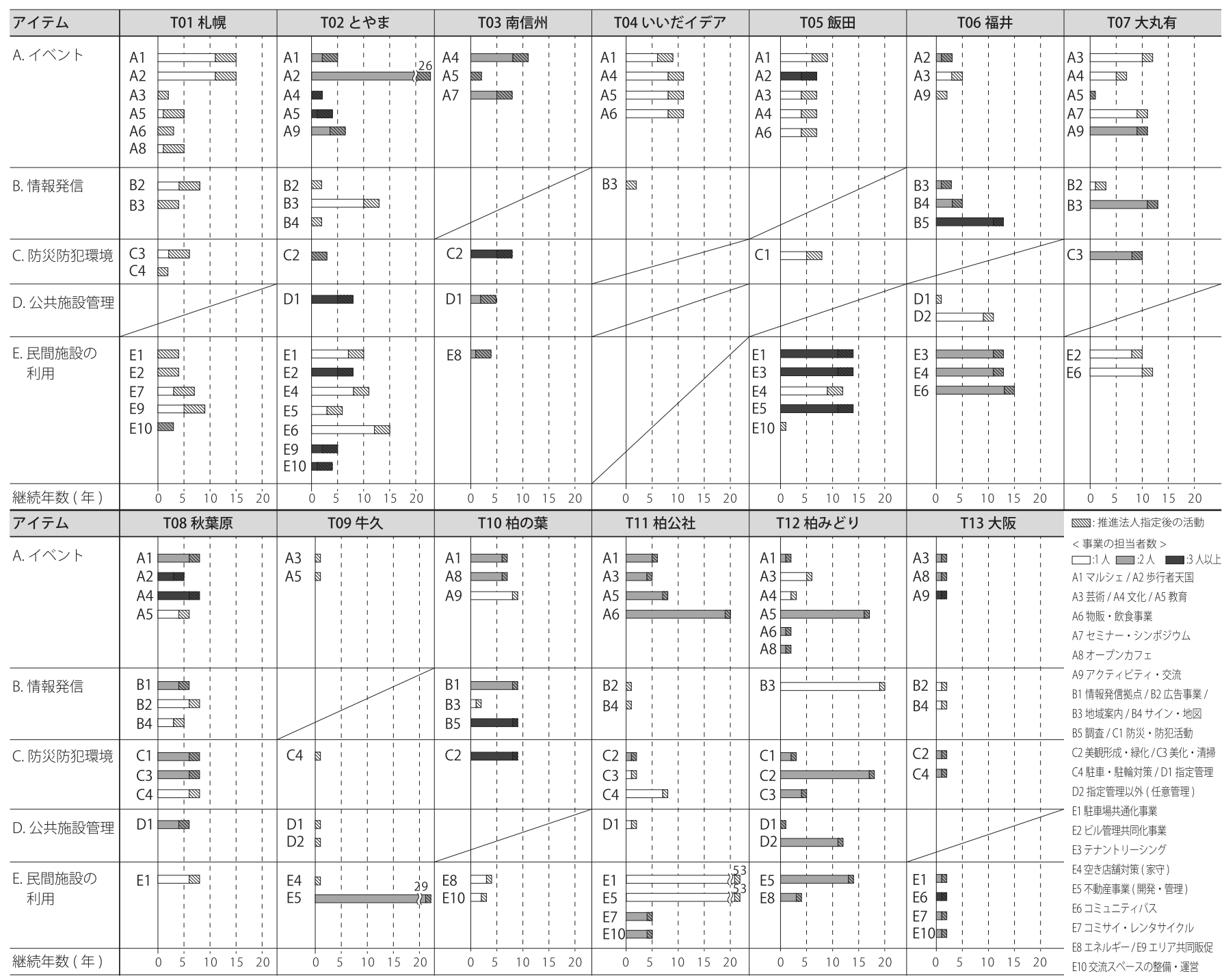

\section{図 4 実施事業の継続年数および都市再生推進法人としての実施年数、担当人数の集計結果}

以上である。また、T05 飯田はまちのにぎわい創出の支援として T04 いいだイデアに活動資金の援助をおこなっている。

$\mathrm{T} 06$ 福井は「B 情報発信」を 3 件、「E 民間施設の利用」を 3 件実 施している点が特徴である。「B5 調査」は中心市街地の空き家状況 を毎年調査し、得られた結果を「E3テナントリーシング」や「E4 空 き店舗対策 (家守)」に活用寸る事業として 13 年継続しており、担 当者数は 3 人以上である。

$\mathrm{T} 07$ 大丸有は「A イベント」を 5 件、「B 情報発信」を 2 件実施し ている点が特徵である。「A9アクティビティ・交流」は東京丸の内 界隈の企業などが参加する野球大会として 11 年継続しており、担当 者数は 2 人である。「B2 広告事業」は屋外広告物ガイドライン ${ }^{11} に$ 基づき掲出している街路灯フラッグバナー広告事業として 3 年継続 しており、担当者数は 1 人である。

T08 秋葉原は「B 情報発信」を 3 件、「C 防災防犯環境」を 3 件実 施している点が特徴である。「B2 広告事業」は街路灯フラッグバナ 一や柱巻きなど駅周辺 9 籄所で実施する広告事業として設立当初か ら 8 年継続しており、担当者数は 1 人である。「C1 防災・防犯活動」 は「Aイベント」実施の際の安全確保や日頃のパトロール事業とし て 8 年継続しており、担当者数は 2 人である。
$\mathrm{T} 09$ 牛久は「D 公共施設管理」を 2 件実施している点が特徵である。 「D1 指定管理」は駅前の行政用地を使用した駐車場および駐輪場の 運営であり、1 年継続しており、担当者数は 1 人である。また、「E5 不動産事業（開発・管理）」は設立した当初からおこなっている駅 前ビルの管理事業として 29 年継続しており、担当者数は 2 人である。

$\mathrm{T} 10$ 柏の葉は「B 情報発信」を 3 件実施している点が特徴である。 「B1 情報発信拠点」は駅前に位置し、「Aイベント」事業の開催場所 にもなっており、設立時から 9 年継続している事業である。「B5 調査」 は行政や大学からの委託事業として 9 年継続しており、担当者数は 3 人以上である。

$\mathrm{T} 11$ 柏公社は「Aイベント」を 4 件、「E民間施設の利用」を 4 件 実施している点が特徵である。「A1 マルシェ」は駅前通りを会場に 地元商店街と連携して 6 年継続している事業であり、「A3 芸術」は 駅前ペデストリアンデッキを会場にした音楽祭として 5 年継続して おり、それぞれ担当者数は 2 人である。「E1 駐車場共通化事業」「E5 不動産事業（開発・管理）」は設立時から 53 年継続しており、担当 者数は 1 人である。

$\mathrm{T} 12$ 柏みどりは「C 防災防犯環境」を 3 件、「D 公共施設管理」を 2 件実施している点が特徵である。「C2 美観形成・緑化」は活動方針 
であるみどりの普及を目的とした花苗植え活動として 18 年継続して おり、担当者数は 2 人である。「D2 指定管理以外 (任意管理等)」は 清掃や美化、維持管理といった公園管理受託事業として 12 年継続し ており、担当者数は 2 人である。

$\mathrm{T} 13$ 大阪は「A イベント」を 3 件、「E民間施設の利用」を 4 件実 施している点が特徴である。「A8 オープンカフェ」は駅前再開発に 伴い街路上のにぎわい創出をおこなう事業として 2 年継続しており、 担当者数は 2 名である。「E6 コミュニティバス」や「E7 コミサイ・ レンタサイクル」はまちの回遊性向上および自動車交通の抑制を目 指す事業として 2 年継続しており、担当者数は 2 人である。

以上より、推進法人毎の事業構成および運用スキームの差異を以 下に述べる。事業構成において、「Aイベント」を高い割合で実施し ている推進法人は、T01 札幌、T03 南信州、T04いいだイデア、T05 飯田、 T07 大丸有、T08 秋葉原、T12 柏みどりの 7 組織である。そのなかで、 T03 南信州、T04 いいだイデア、T07 大丸有は実施数が過半を占めて いる。さらに、T04いいだイデアと T07 大丸有は担当者数が 1 人で、 $\mathrm{T} 03$ 南信州は担当者数が 2 人で 10 年程度継続している。

事業構成において、「E民間施設の利用」を高い割合で実施してい る推進法人は、T02 とやま、T05 飯田、T11 柏公社、T 13 大阪の 4 組 織である。そのなかで、T02 とやまは担当者数が 1 人から 3 人以上 と事業により異なる一方で、 13 大阪は各事業の担当者数が 2 人か ら 3 人以上と複数人であった。

\section{3. 事業継続性からみるエリアマネジメントの実態}

収益構成比の視点から推進法人によるエリマネの実態を明らかに するために $\mathrm{ABC}$ 分析 ${ }^{\sharp 10)}$ をおこない、各推進法人による実施事業を A 判定 0-80\% (以下、A 判定) 事業、B 判定 81-90\% 事業、C 判定 91$100 \%$ 事業に分類し、パレート図を作成する ${ }^{\sharp 11}$ 。

パレート図の作成にあたり、エリマネによる収益とは異なる支援 金事業も併せて分析寸るためにアイテム「F支援金事業」を設定し、 各推進法人の事業継続性を明らかに寸る。「F支援金事業」のカテゴ リーを表 4 に、各判定に該当する事業を図 5 に、各推進法人のパレ 一ト図を図 6 に示す。

\section{1. 収益性の高い事業ついて}

各推進法人の実施事業において、収益性の高い事業内容を明らか にするために A 判定事業に着目してみていく。

はじめに、図 5 より、A 判定に該当するアイテムをみると、「Aイ ベント」が 1 件、「B 情報発信」が 4 件、「C 防災防犯環境」が 1 件、「D 公共施設管理」が 2 件、「E民間施設の利用」が 6 件、「F 支援金事業」 が 5 件あることがわかる。また、「 情報発信」や「E民間施設の利用」 により地域の魅力や価值、利便の増進を計りながら収益を確保して いる推進法人がある一方で、「F 支援金事業」による援助を受けるこ とで事業を実施している推進法人があると考えられる。

さらに、A 判定に該当するカテゴリーをみると、「B2 広告事業」が 3 件と最も多く、次いで「E1 駐車場共通化事業」「F1 会費」「F2 補助 金」が 2 件であることがわかる。これは、「B2 広告事業」によるま ちの情報発信を目指寸事業や「E1 駐車場共通化事業」による来街者 促進を目指寸事業は、中心市街地や駅前を訪れる多くの人々をター ゲットにした事業であり、広告掲載や駐車場提携・連携を申し出る 民間事業者が現れるため、収益性が高いと考えられる。
表 4 支援金事業のアイテムとカテゴリー

\begin{tabular}{ll|l}
\hline アイテム & カテゴリー & 説明 \\
\hline$F$ 支援金事業 & $F 1$ 会費 & 「推進法人の構成員」から「推進法人」へ渡る収益 \\
& $F$ 補助金 & 「行政」から「推進法人」へ渡る収益 \\
& $F 3$ 協賛金等 & 「民間企業」から「推進法人」へ渡る収益 \\
\hline
\end{tabular}

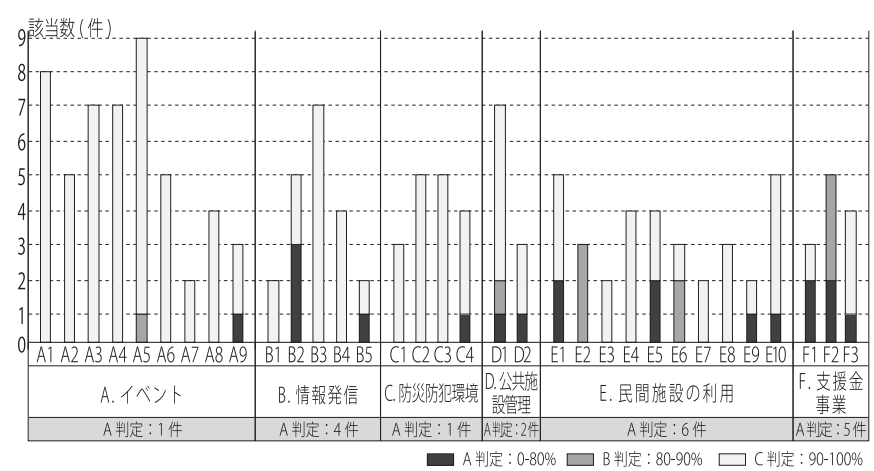

図 5 各判定に該当する事業

\section{2. 各都市再生推進法人による事業継続性の確保について}

各推進法人による事業継続性の確保を明らかにするために、A 判 定事業における収益構成比やその事業収益が固定収益か流動収益 ${ }^{* i 12}$ かを把握し、さらに A 判定事業の運用スキームをみていく洋13)。

図 6 より、T01 札幌の A 判定事業における固定収益をみると、「E1 駐車場共通化事業」の収益構成比が $30.0 \%$ 、「E10 交流スペースの整 備・運営」の収益構成比が $25.0 \%$ である一方で、流動収益をみると、 「B2 広告事業」の収益構成比が $20.0 \%$ でる。これより、T01 札幌は 継続年数が 5 年程度かつ担当者数が 1-2 人という運用スキームに基 づき、固定収益を生む $\mathrm{A}$ 判定事業を複数件実施することで事業継続 性を確保していることがわかる。

T02 とやまの A 判定事業における固定収益をみると、「E1 駐車場共 通化事業」の収益構成比が $45.8 \%$ 、「E9 エリア共同販促」の収益構成 比が 7. $0 \%$ である。一方で、流動収益をみると、「F2 補助金」の収益 構成比が $24.7 \%$ である。これより、T02 とやまは継続年数が 10 年以 上かつ担当者数が複数人という運用スキームに基づき、固定収益を 生む $\mathrm{A}$ 判定事業を複数件実施することで事業継続性を確保している ことがわかる。

T03 南信州の A 判定事業における固定収益をみると、「D1 指定管理」 の収益構成比が $82.4 \%$ である。一方で、流動収益をみると、該当す る事業がない。これより、T03 南信州は「D1 指定管理」から収益を 得ており、継続年数が 5 年かつ担当者数が 2 人という運用スキーム に基づき、固定収益を生む $\mathrm{A}$ 判定事業を 1 件実施することで、事業 継続性を確保していることがわかる。

T04 いいだイデアの A 判定事業における固定収益をみると、該当す る事業がない。一方で、流動収益をみると、「F1 会費」「F2 補助金」 それぞれの収益構成比が 50.0\%である。これより、T04いいだイデア は「F支援金事業」から収益を得ており、流動収益を生む $\mathrm{A}$ 判定事業 を複数件実施することで事業継続性を確保していることがわかる。

T05 飯田の A 判定事業における固定収益をみると、「E5 不動産事業 (開発・管理)」の収益構成比が $65.1 \%$ である。一方で、流動収益を みると、該当する事業がない。これより、T05 飯田は「E5 不動産事 業 (開発・管理)」から収益を得ており、継続年数が 10 年かつ担当 者数が 3 人という運用スキームに基づき、固定収益を生む $\mathrm{A}$ 判定事 
業を 1 件実施することで事業継続性を確保していることがわかる。

$\mathrm{T} 06$ 福井の A 判定事業における固定収益をみると、該当する事業 がない。一方で、流動収益をみると、「F2 補助金」の収益構成比が
60. 0\%である。これより、T06 福井は「F2 補助金」から収益を得ており、 流動収益を生む A 判定事業を 1 件実施することで事業継続性を確保 していることがわかる。

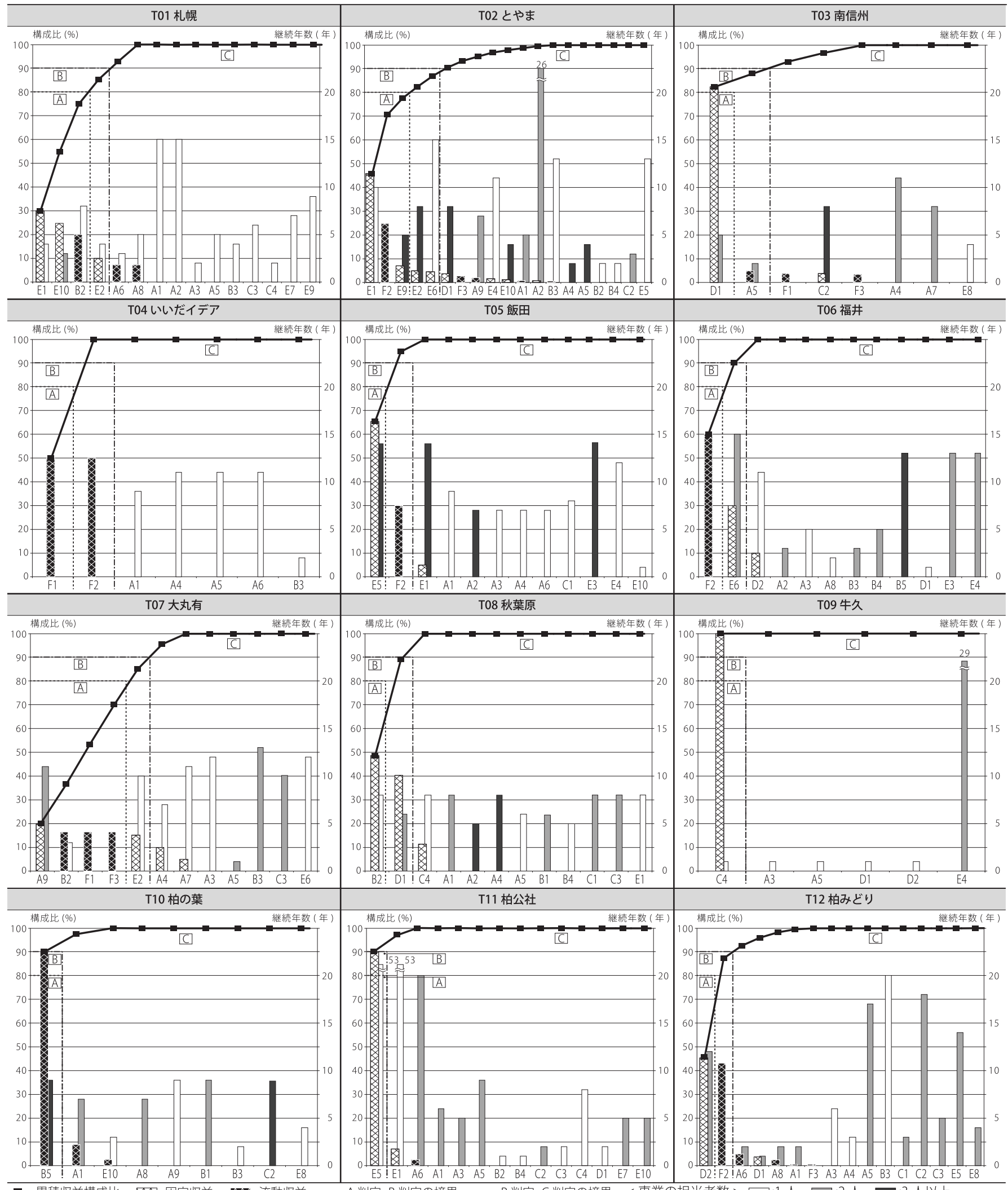

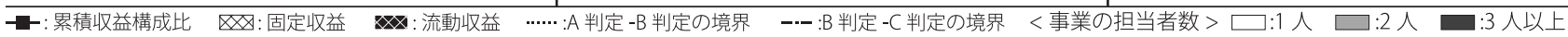

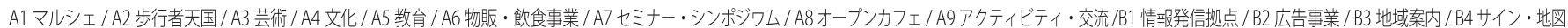

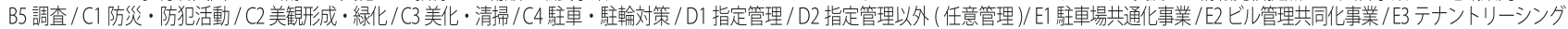
E4 空き店舗対策(家守)/E5 不動産事業(開発・管理)/E6 コミュニティバス/E7 コミサイ・レンタサイクル/E8 エネルレギー/E9 Iリア共同販促/E10交流スペースの整備・運営/F1会費/F2 補助金/F3協賛金 
$\mathrm{T} 07$ 大丸有の A 判定事業における固定収益をみると、「A9アクティ ビティ・交流」の収益構成比が $20.0 \%$ である。一方で、流動収益を みると、「B2 広告事業」の収益構成比が $16.7 \%$ 、「F1 会費」の収益構 成比が $16.7 \%$ 、F 3 協賛金等」の収益構成比が $16.7 \%$ である。これよ り、 $\mathrm{T} 07$ 大丸有は継続年数が 10 年程度かつ担当者数が複数人という 運用スキームに基づき、流動収益を生む $\mathrm{A}$ 判定事業を複数件実施す ることで事業継続性を確保していることがわかる。

$\mathrm{T} 08$ 秋葉原の A 判定事業における固定収益をみると、「B2 広告事業」 の収益構成比が $48.4 \%$ あるる。一方で、流動収益をみると、該当す る事業がない。これより、T08 秋葉原は「B2 広告事業」から収益を 得ており、継続年数が 8 年かつ担当者数が 1 人という運用スキーム に基づき、固定収益を生む $\mathrm{A}$ 判定事業を 1 件実施することで事業継 続性を確保していることがわかる。

T09 牛久の A 判定事業における固定収益をみると、「C4 駐車・駐輪 対策」の収益構成比が $100 \%$ である。一方で、流動収益をみると、該 当する事業がない。これより、T09 牛久は「C4 駐車・駐輪対策」か ら収益を得ており、継続年数が 1 年かつ担当者数が 1 人という運用 スキームに基づき、固定収益を生む $\mathrm{A}$ 判定事業を 1 件実施すること で事業継続性を確保していることがわかる。

$\mathrm{T} 10$ 柏の葉の A 判定事業における固定収益をみると、該当する事 業がない。一方で、流動収益をみると、「B5 調查」の収益構成比が 90. 0\%である。これより、T10 柏の葉は「B5 調查」から収益を得ており、 継続年数が 9 年かつ担当者数が 3 人以上という運用スキームに基づ き、流動収益を生む A 判定事業を 1 件実施することで事業継続性を 確保していることがわかる。

$\mathrm{T} 11$ 柏公社の A 判定事業における固定収益をみると、「E5 不動産 事業 (開発・管理)」の収益構成比が $90.0 \%$ である。一方で、流動 収益をみると、該当する事業がない。これより、T11 柏公社は「E5 不動産事業（開発・管理）」から収益を得ており、継続年数が 53 年かつ担当者数が 1 人という運用スキームに基づき、固定収益を 生む $\mathrm{A}$ 判定事業を 1 件実施することで事業継続性を確保している ことがわかる。

$\mathrm{T} 12$ 柏みどりの A 判定事業における固定収益をみると、「D2 指定管 理以外 (任意管理)」の収益構成比が $45.0 \%$ である。一方で、流動 収益をみると、該当する事業がない。これより、T12 柏みどりは「D2 指定管理以外 (任意管理)」から収益を得ており、継続年数が 12 年 かつ担当者数が 2 人という運用スキームに基づき、固定収益を生む $\mathrm{A}$ 判定事業を 1 件実施することで事業継続性を確保していることが わかる。

以上より、固定収益を生むA 判定事業を実施している推進法人毎 の収益事業構造および運用スキームの差異を以下に述べる。固定収 益を生む $\mathrm{A}$ 判定事業を複数件実施している推進法人は、T01 札幌と $\mathrm{T} 12$ とやまである。そのなかで、T 01 札幌は担当者数が 1 人か 2 人で あるのに対し、T12 とやまは担当者数が 1 人から 3 人以上と事業に よって異なる。

固定収益を生む $\mathrm{A}$ 判定事業を 1 件実施している推進法人は、T03 南信州、T05 飯田、T08 秋葉原、T09 牛久、T11 柏公社、T12 柏みど りの 6 組織と最も多い。そのなかで、T08 秋葉原、T09 牛久、T11 柏 公社は担当者数が 1 人であるのに対し、T03 南信州、T 05 飯田、T 12 柏みどりは担当者数が 2 人から 3 人以上と複数人であった。
表 5 制度のアイテムとカテゴリー

\begin{tabular}{|c|c|c|}
\hline アイテム & カテゴリー & 説明 \\
\hline \multirow[t]{4}{*}{ G 制度 } & G1 道路占有許可の特例 & $\begin{array}{l}\text { にぎわい創出等に資するために韻路を占用する場合、 } \\
\text { 許す可基準の特例制度 }\end{array}$ \\
\hline & G2 都市再生整備整備計画の提案 & $\begin{array}{l}\text { 推進法人が行おうとしている事業を公的な計画である } \\
\text { 都市再生整備計画に位置付ることが可能 }\end{array}$ \\
\hline & G3 都市利便増進協定 & $\begin{array}{l}\text { 地域のまちづくりを地域住民が自主的に行うだめの } \\
\text { 協定制度に地権者以外では唯一参画が可能 }\end{array}$ \\
\hline & G4 民間まちづくり活動促進事業 & $\begin{array}{l}\text { 都市再生法人が主体となったまちづくり計画・協定に } \\
\text { 基づく施設整備等に対する補助制度 }\end{array}$ \\
\hline
\end{tabular}

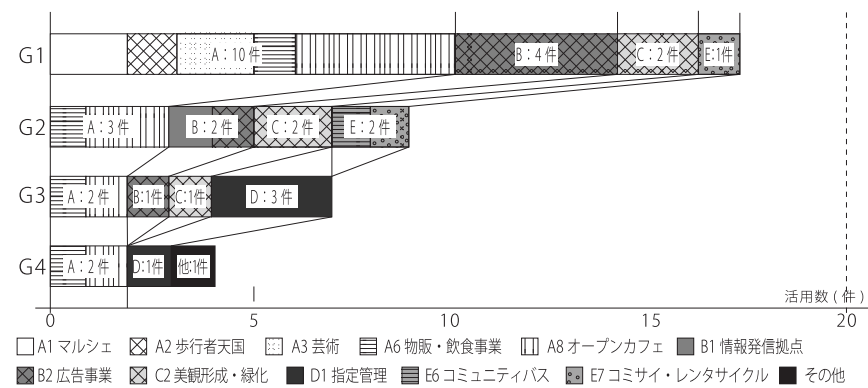
図 7 制度活用の実態

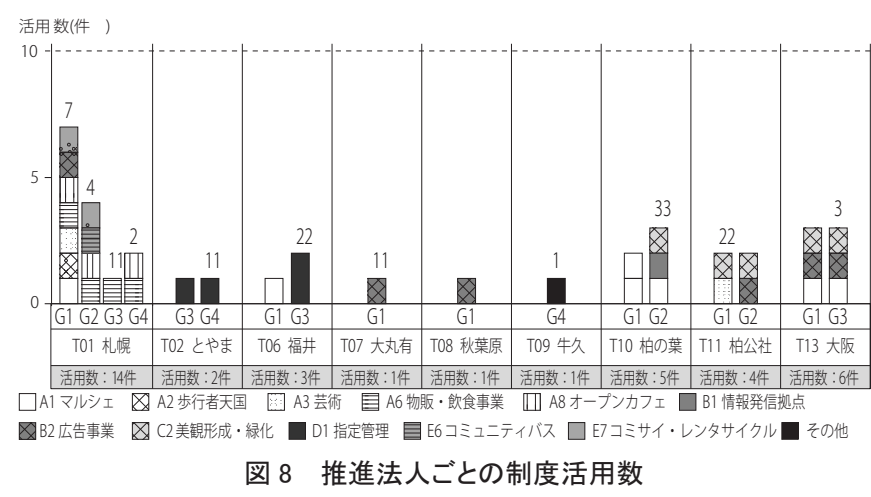

\section{4.「都市再生推進法人」制度の活用実態}

法人制度の活用実態を明らかにするために、各推進法人がどの事 業に法人制度を活用しているかをみていく。活用が可能である法人 制度はいくつかあるが、ヒアリング調查の結果をふまえて、現在、 各推進法人が活用している 4 つの制度を抽出し、アイテム「G 制度」 を設定した。「G 制度」のカテゴリーを表 5 に示す。設定した「G 制度」 における制度活用の実態を図 7 に、推進法人ごとの制度活用数を図 8 に示す。

各制度の活用数および活用実態をみていく。図 7 より、「G1 道路 占有許可の特例」（以下、「G1 道路特例」）をみると、活用数が 17 件であり、その内訳は「Aイベント」の 10 件が最も多く、次いで「B 情報発信」の 4 件である。これは、道路占有によるにぎわい創出を 目的とした「A2 歩行者天国」や街路灯フラッグバナーなどによる情 報発信を目的とした「B2 広告事業」に活用されているためである。

「G2 都市再生整備計画」をみると、活用数が 9 件であり、その内 訳は「Aイベント」の 3 件が最も多く、次いで「B 情報発信」「C 防 災防犯環境」「E民間施設の利用」の 2 件である。これは、推進法人 が実施するすべての事業に公的な位置付けを与えるために、活用数 が偏ることなく均質化されたと考えられる。

「G3 都市利便増進協定」をみると、活用数が 7 件であり、その内 訳は「D 公共施設管理」の 3 件が最も多く、次いで「Aイベント」の 2 件である。これは、再開発などにより施設管理を担う推進法人が 周辺地区のまちづくりを自主的におこなうために、「D1 指定管理」 
における協定締結地区のにぎわい創出拠点となる「A5 物販・飲食事業」 「A8 オープンカフェ」に活用されているためである。

「G4 民間まちづくり活動促進事業」（以下、「G4 民まち事業」）を みると、活用数が 4 件であり、その内訳は「Aイベント」の 2 件が 最も多く、次いで「D 公共施設管理」「その他」の 1 件である。これは、 街路上に設置する「A6 物販・飲食事業」「A8 オープンカフェ」や公 共広場に音響装置およびミス卜装置を設置する「D1 指定管理」の初 期費用の確保に活用されたためである。

次に、推進法人ごとに法人制度の活用数と制度活用による事業収 益の確保における現状をみていく。図 8 より、法人制度の活用数は、 $\mathrm{T} 01$ 札幌の活用数が 14 件と最も多く、次いで、 $\mathrm{T} 13$ 大阪が 6 件、T10 柏の葉が 5 件である。一方で、T03 南信州、T04いいだイデア、T05 飯田、 T12 柏みどりが制度活用をしていないことがわかる。

また、図 6 より、制度活用による収益の確保は、T01 札幌、T13 大阪、 $\mathrm{T} 10$ 柏の葉が、法人制度を活用することで実施している事業をみる と、A 判定事業であり固定収入を確保しているものがない洋13)。一方で、 T03 南信州、T04いいだイデア、T05 飯田、T12 柏みどりが、実施し ている事業をみると、A 判定事業であり固定収益を確保しているも のがある。これらより、法人制度を活用することは、A 判定事業に おける固定収益の確保につながらないことがわかる。

以上より、1つの制度活用により実施可能な事業を明らかにした。 さらに、複数の制度活用により実施可能な事業をみると、「A6 物販・ 飲食事業」「A8 オープンカフェ」「C2 美観形成・緑化」「E7 コミサイ・ レンタサイクル」は、「G2 都市再生整備計画」または「G3 都市利便 増進協定」を活用した上で、併せて「G1 道路特例」を活用すること で実施可能な事業である。これは、「A2 歩行者天国」や「B2 広告事業」 のように仮設事業ではなく、施設や機器の設置を伴う常設事業は、「G2 都市再生整備計画」または「G3 都市利便増進協定」で協定締結地区 を定めてから「G1 道路特例」を活用寸る必要があるためである。

また、法人制度の活用と事業収益の確保における関係を明らかに した。推進法人が法人制度を活用し、A 判定事業における固定収益 の確保をおこなわないのは、その事業を運用するための人員が不足 していることが考えられる。そこで、収益の確保や向上を目指した 事業を実施するために、法的支援など法人制度の活用範囲を拡充す る必要があると推察される。

\section{5. まとめ}

本研究では、推進法人によるエリマネの実態を把握するために、 実施事業に着目し、各推進法人における事業の継続年数および担当 人数を明らかにした。また、事業継続性の確保に着目し、ABC 分析 によるパレート図を作成することで収益性の高い事業およびその運 用スキームを明らかにした。さらに、法人制度の活用数およびその 内容を明らかにすることで、制度活用の実態を把握した。本研究で 得られた知見を表 6 に示す。

表 6 より、T01 札幌は、すべての制度を活用している。さらに、「G1 道路特例」と「G3 都市利便増進協定」を、「A6 物販・飲食事業」「A8 オープンカフェ」「B2 広告事業」といった収益事業に活用すること で収益事業を確保している。

T02 とやまは、「G3 都市利便増進協定」と「G4民まち事業」を、「D1 指定管理」に活用寸ることで収益事業を確保している。また、「E民
表 6 都市再生推進法人によるエリアマネジメントの実態

\begin{tabular}{|c|c|c|c|c|c|c|}
\hline & & 4 章 [ 事業 ] & & 5 章 [ 収益 ] & 6 章 [ 制度 ] & 特徵 \\
\hline $\begin{array}{l}\text { T01 } \\
\text { 札 } \\
\text { 幌 }\end{array}$ & 構 & 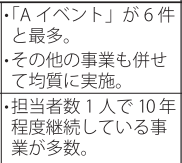 & 㝘 & $\begin{array}{l}\text { · }[\text { E1 駐車場共通化事業】 } \\
\text { の收益構成がが } \\
\text { と最多。 }\end{array}$ & 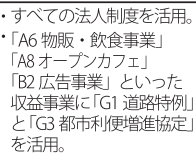 & 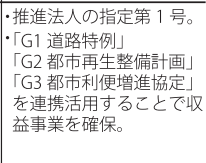 \\
\hline $\begin{array}{l}\text { T02 } \\
⿱ 亠 \\
や \\
\text { ま }\end{array}$ & 構 & 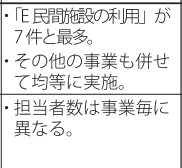 & 芯 & $\begin{array}{l}\text { · } \text { ·E1駐車場共通化事業 } \\
\text { の収益構成が } \\
\text { と最多。 }\end{array}$ & 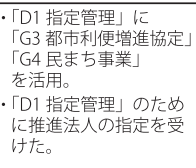 & $\begin{array}{l}\cdot \text { 実施事業数が全推進法人 } \\
\text { の中で最多。 } \\
\text { ·「E民民間施設の利用」が } \\
7 \text { 件と全推進法人の中で } \\
\text { 最多。 } \\
\text { ·富山市のTMO(第二セクター)。 }\end{array}$ \\
\hline $\begin{array}{l}\text { T03 } \\
\text { 南 } \\
\text { 信 } \\
\text { 州 }\end{array}$ & 容 & $\begin{array}{l}\text { •「Aイベント」が } 6 \text { 件 } \\
\text { と实施事業の通半を } \\
\text { 占める。 }\end{array}$ & \begin{tabular}{|l|} 
容 \\
\end{tabular} & $\begin{array}{l}\text { ·固定収益を生むA 判 } \\
\text { 定事業を } 1 \text { 件実施。 }\end{array}$ & $\begin{array}{l}\text { 行政からの公幕のもと、り } \\
\text { 公的なまちづく組織 } \\
\text { 位置づけの取得をね } \\
\text { らい推進法人の指定 } \\
\text { を受けた。 } \\
\text { 今後も制度活用の予定 } \\
\text { なし。 }\end{array}$ & $\begin{array}{l}\text { 全国唯一の環境省推進 } \\
\text { 事業「D1 指定管理」を } \\
\text { 成功させ、A A判定事業 } \\
\text { の固定収益事業としてて } \\
\text { 運用している。 }\end{array}$ \\
\hline 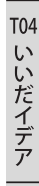 & \begin{tabular}{|l} 
構 \\
成 \\
蓉 \\
\end{tabular} & $\begin{array}{l}\text { •「Aイベント」が } 5 \text { 件 } \\
\text { と特化しており } \\
\text { 10年程度継䊦して央施。 }\end{array}$ & 構. & $\begin{array}{l}\Gamma \text { 支援金事業」から } \\
\text { 収益を得ている。 } \\
\text { T05 飯田から活動資金 } \\
\text { の援助を受けている。 } \\
\end{array}$ & 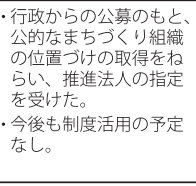 & 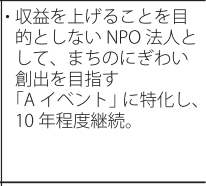 \\
\hline $\begin{array}{l}\text { T05 } \\
\text { 飯 } \\
\text { 田 }\end{array}$ & 容 & \begin{tabular}{|l|}
$\cdot \Gamma A$ 「A゙ント」 \\
「E民間施設の利用」 \\
がそれそれ \\
化している件と特 \\
「E民間施設の利用」 \\
は担当数が3人上上。
\end{tabular} & 内容 & $\begin{array}{l}\cdot \text { ·EE 不動産事業(開発· } \\
\text { 管理)」 } \\
\text { の収益構成比が } 65.1 \% \\
\text { と多多。 } \\
\end{array}$ & 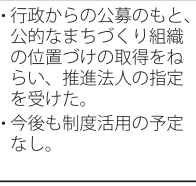 & 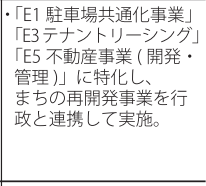 \\
\hline $\begin{array}{l}\text { T06 } \\
\text { 福 } \\
\text { \# }\end{array}$ & 内容 & 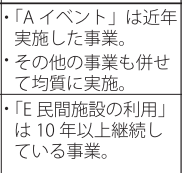 & 容 & $\begin{array}{l}\text { ·流動収益を生むA 判 } \\
\text { 定事業を1 件実施。 }\end{array}$ & $\begin{array}{l}\text { •「D1 指定管理」に } \\
\text { 「G3 都市利便増進協定」 } \\
\text { を活用。 } \\
\text { • 「A8 オープンカフフ」に } \\
\text { 「G1 道路特例」と } \\
\text { 「G3 都市利便增進協定」 } \\
\text { を活用。 }\end{array}$ & 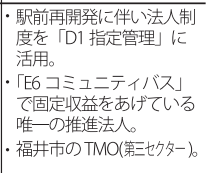 \\
\hline $\begin{array}{l}\text { T07 } \\
\text { 大 } \\
\text { 茇 } \\
\end{array}$ & 容 & 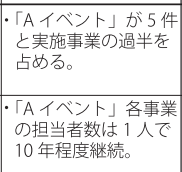 & 蓉 & $\begin{array}{l}\text { •「A9アクテイビティ. } \\
\text { 交流」の収益構成比 } \\
\text { 20.0\% と敢。 }\end{array}$ & $\begin{array}{l}\text { • 公的なまちづくり組織 } \\
\text { の位置づけの取得をね } \\
\text { らい推進法人の指定 } \\
\text { を受けた。 } \\
\text { ·「B2 広告事業」に「G1 } \\
\text { 道路特例」を活用。 }\end{array}$ & 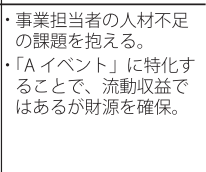 \\
\hline $\begin{array}{l}\text { T08 } \\
\text { 秋 } \\
\text { 葉 } \\
\text { 原 }\end{array}$ & 容 & $\begin{array}{l}\text { ·設立当初から䒠施し、 } \\
5 \text { 年ら } 8 \text { 年縍し } \\
\text { ている事業か多数。 }\end{array}$ & 内容 & $\begin{array}{l}\text { 固定収益を生むA 判 } \\
\text { 定事業を } 1 \text { 件実施。 }\end{array}$ & 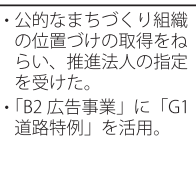 & 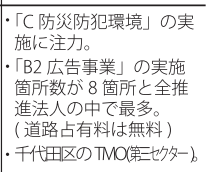 \\
\hline $\begin{array}{l}\text { T09 } \\
\text { 牛 } \\
\text { 久 }\end{array}$ & 蓉 & $\begin{array}{l}\cdot \text { すべての担当者数が } \\
1 \text { 人で、継続年が } \\
1 \text { 年。 }\end{array}$ & 蓉 & $\begin{array}{l}\cdot \Gamma C 4 \text { 駐車・駐輪対策 } \\
\text { の収益構成比 } 100 \% \\
\text { と聚多。 }\end{array}$ & $\begin{array}{l}\text { ·まちづくり協議会を設 } \\
\text { 立する際活用。 } \\
\text { 事業」ちち } \\
\text { ·駅前広場の開発に伴い、 } \\
\text { 「G1 道路特例」 } \\
\text { 「G33 都市利便增進協定」 } \\
\text { の導入を検討。 }\end{array}$ & 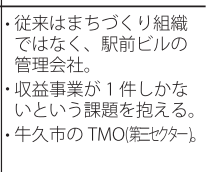 \\
\hline $\begin{array}{l}\mathrm{T} 10 \\
\text { 柏 } \\
\text { の } \\
\text { 葉 }\end{array}$ & 構 & 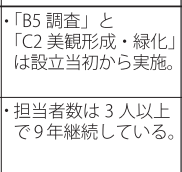 & 構 & $\begin{array}{l}\text { •流動収益を生むA 判 } \\
\text { 正事業を } 1 \text { 件実施。 }\end{array}$ & 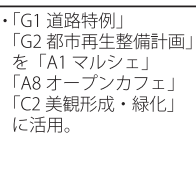 & $\begin{array}{l}\text { •駅前開発を推進する } \\
\text { 産学官連携の組織が、 } \\
\text { 活動斯源を確保するた } \\
\text { めに指定をた。 } \\
\text { (道路占有料は無料) }\end{array}$ \\
\hline $\begin{array}{l}\mathrm{T} 11 \\
\text { 柏 } \\
\text { 公 } \\
\text { 社 }\end{array}$ & $\mid \begin{array}{l}\text { 構 } \\
\text { 出 }\end{array}$ & $\begin{array}{l}\cdot \text { ·Aイベント」は } \\
\text { 担当者数が } 1 \text { 人。 } \\
\cdot \text { ·E民間施設の利用」 } \\
\text { は担当者数が 2人。 } \\
\end{array}$ & 内容 & $\begin{array}{l}\cdot \Gamma[E 5 \text { 不動産事業(開発 } \\
\text { 管理)」双益構成此 } \\
\text { が } 90.0 \% \text { 取多。 }\end{array}$ & 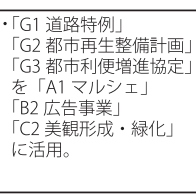 & $\begin{array}{l}\text { ·駅前に日本最古のペデス } \\
\text { トリアンデッキを有し、 } \\
\text { 「G1 道路占有」を活用。 } \\
\text { (道路占有料は無料) } \\
\text { ·設立年が } 1962 \text { 年と全推 } \\
\text { 進法人の中で最も古い。 }\end{array}$ \\
\hline $\begin{array}{l}\mathrm{T} 12 \\
\text { 柏 } \\
\text { ぬ } \\
\text { 〔゙ }\end{array}$ & & $\begin{array}{l}\text { · 「C防災防犯環境」の } \\
\text { 奉施が主目的であり } \\
\text { 担当者数は必ず } 2 \text { 人。 }\end{array}$ & 構 & $\begin{array}{l}\text { ·固定収益を生む A 判 } \\
\text { 定事業を1 件実施。 }\end{array}$ & $\begin{array}{l}\text { ·公的なまちづくり組織 } \\
\text { の位置づけの取得をね } \\
\text { らい推進法人の指定 } \\
\text { を受けた。 } \\
\text { ·今後も制度活用の予定 } \\
\text { なし。 }\end{array}$ & $\begin{array}{l}\text { ·事業担当者の人材不足 } \\
\text { 課題を抱える。 } \\
\text { •DD公共施設管理」によ } \\
\text { る固定収益の確保を目 } \\
\text { 指す。 }\end{array}$ \\
\hline $\begin{array}{c}\text { 大 } \\
\text { 服 }\end{array}$ & 構| & 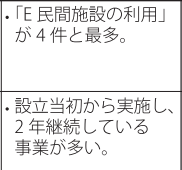 & 構| & & 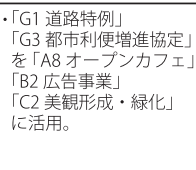 & $\begin{array}{l}\text { •「G3 都市利便増進協定」 } \\
\text { の活用を目指Lて指定 } \\
\text { を受けたた。 } \\
\text { •地権者からの共同急担 } \\
\text { 金を原資とL事業を } \\
\text { 実施すBID制度を導入。 } \\
\text { ·大阪市のTMO。 }\end{array}$ \\
\hline
\end{tabular}


間施設の利用」の実施数が全推進法人のなかで最多であり、こちら からも収益事業を確保している。一方で、「G1 道路特例」を活用し た事業を実施していない。

$\mathrm{T} 06$ 福井、T10 柏の葉、T11 柏公社、T13 大阪のように、再開発に 伴う駅前広場および街路空間で事業を実施する推進法人は、「G2 都 市再生整備計画」または「G3 都市利便増進協定」を活用した上で、 併せて「G1 道路特例」を活用することで、協定締結地区のにぎわい 創出や維持管理をおこなっている。

T09 牛久は、「G4 民まち事業」を、地域のまちづくり協議会の設立 に活用することで活動資金を確保している。また、設立時から実施 している「E5 不動産事業 ( 開発・管理)」による収益は、エリマネ に充当しない方針を定めているため、「C4 駐車・駐輪対策」以外に 新たな収益事業を確保することが課題である。

このように、法人制度を効果的に活用する推進法人がいる一方で、 T03 南信州、T04 いいだイデア、T05 飯田、T07 大丸有、T08 秋葉原、 T12 柏みどりのように、指定以前から行政と連携している推進法人 は、制度活用することで実施できる事業を指定以前から実施してい

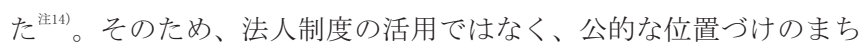
づくり組織を目指して推進法人の指定を受けている。

そのなかで、T07 大丸有と T08 秋葉原は、「G1 道路特例」を、「B2 広告事業」に活用することで収益事業を確保している。一方で、T03 南信州、T04いいだイデア、T05 飯田は、飯田市の公募により推進法 人に指定されており、法人制度を活用した事業を実施しておらず、 今後も法人制度を活用した事業を実施する予定がない。また、T12 柏みどりも、法人制度を活用した事業を実施しておらず、今後も法 人制度を活用した事業を実施する予定がない。

以上より、法人制度の活用状況が各推進法人で異なることが明ら かになった。推進法人によるエリマネの事業継続性の確保に向けて、 収益を生む事業に対して法人制度の活用範囲を拡充することが必要 であると考えられる。

また、エリマネは事業収益の高い事業で得た収益を、賑わい創出 や公共還元事業に充当寸る循環が重要である。指定管理や駐車場経 営といった、運用マニュアル・ルールが定まり、人的配置の少ない 事業が収益を確保している。

一方で、賑わい創出や公共還元のためのイベントや景観形成・緑化 といった、機材・備品の手配、イベント当日の運営をおこなう人物の 養成など、人的配置の多い事業は収益の確保が困難であるとわかった。 そこで、人的配置が多く、事業収益の確保が難しい、賑わい創出 や公共還元のための事業に対しても、法人制度の活用範囲を拡充す ることで、法的支援による人的配置の軽減、運営をスムーズにおこ なうことが可能となり、より良いエリマネが実現するだろう。

本研究では、調查開始時 (2014 年 7 月) に推進法人に指定された 15 組織を対象にエリマネの実態を把握したが、2015 年 10 月現在、 推進法人の指定数は 21 組織となっている。今後は、各団体における 設立時の状況把握を課題とし、新たに指定された推進法人に対して も同様に調查をおこなうことを展望とする。

\section{謝辞}

本研究にご協力いただいた推進法人の皆様および行政関係者の皆 様に深く感謝申し上げます。
注

注 1）我が国の「成長への道筋」を害行・赛現するものとして、「日本産業再 興プラン」「戦略市場創造プラン」および「国際展開戦略」の 3 つのア クションプランを 2013 年に打ち出しており、「日本産業再興プラン」の なかでコンパクトシティについて議論されている。

注 2）都市における一定の人口密度を維持することで、医療、福祉、買物といっ た生活サービスの提供が維持されるよう、集約型都市構造に向けた戦略。

注 3) (1)都市再生整備計画の提案、(2)都市利便增進協定への参画、(3)市町村や 国等による支援など主に 7 つの事項がある。

注 4）国または地方公共団体（第一七クター）が民間企業（第二セクター）と 共同出資によって設立した法人。

注 5） 3 段階の調查を実施できなかった 14 およびT15を調查対象から除外した。

注 6) [ 収益構成比 $=$ 事業収益 / 年間収益] により算出した。

注 7）参考文献9）pp12 に使用されている「エリアマネジメントの要素」6アイ テム30カテゴリーと、参考文献 10) p p4 に使用されているアイテムカテ ゴリーの設定を参照し、調査で明らかにした事業の分類においてカテゴ リーとアイテムの省略・追加・細分化をおこない、 5 アイテム 30 カテゴリー を設定した。

注 8）調査結果より、事業の担当人数は「1 人による専任制」「 22 人による主 担当および副担当制」「 3 人以上」の 3 つのパターンが得られたため、 これらをもとに図表を示す。

注 9）環境省エコハウスモデル事業は、応募の中で選ばれた全国 20 の自治体 が、環境省の補助金を受け、それぞれの地域の気候風土や特色を生かし たエコハウスの実現と普及に取り組む事業である。

注 10) 在庫管理や販売管理など経営面で重点管理を行う際に、要素項目の重要 度や優先度を明らかにするための分析手法。パレート図をツールとして 管理対象を重要な順に $\mathrm{A} ・ \mathrm{~B} ・ \mathrm{C}$ の 3 つのランクに分ける。

注 11) 本研究では、収益性の高い事業を中心に扱うためにAランクの領域を大 きくし、累計構成比の上位から、0-80\%を A 判定、81-90\%を B 判定、 91-100\%をC 判定とした。

注 12）年度によって事業収益が变動しないと回答いただいた収益を固定収益、 変動すると回答いただいた収益を流動収益とした。

注 13）T13 の収益構成比は非公表情報のため、T01-12 の全 12 サンプルを対象 に分析をおこなった。

注 14）道路占有による広告事業や歩行者天国などを、行政と連携することで推 進法人の指定前から実施している。

\section{参考文献}

1）官民連携まちづくりの進め方一都市再生特別措置法に基づく制度の活用手 引き一：国土交通省都市局まちづくり推進課官民連携推進室, 2012

2）中心市街地活性化ハンドブック：国土交通省都市局まちづくり推進課, 2015

3）市街地整備におけるエリアマネジメントの手引：東京都都市整備局, 2011

4）都市再生整備計画を活用した官民連携方策検討調查報告書 : 国土交通省都 市局まちづくり推進課, 2011

5）特定非営利活動法人制度のしくみ：内閣府大臣官房市民活動促進課，2012

6) 浅井孝彦, 森田佳綱, 内海麻利, 小林重敬, 南珍 : 大都市都心部における エリアマネジメントの実態に関する研究, 日本都市計画学会学術研究論文 集,第 37 回,pp. 601-606, 2002

7）芦野光憲, 稲田和美, 浅野光行: 都市再生整備推進法人の導入要件と導入 支援策に関寸る研究一まちづくりの担い手裙野拡大の実現に向けて, 日本 都市計画学会都市計画報告集, No. 6, pp. 44-50，2007.8

8）泉山鲢威，小林正美：地方都市型エリアマネジメントの視点から見た「都 市再生整備推進法人」制度に関する研究一まちづくり会社等による公共空 間活用等による収益事業の確保の可能性と課題 -, 日本建築学会大会学術講 演梗概集，都市計画 , pp. 827-830，2013.8

9）社会資本整備審議会都市計画・歴史的風土分科会都市計画部会 第 3 回新た な時代の都市マネジメント小委員会 配布資料：国土交通省都市局, 2015

10)内田晃, 岩田司, 出口敦 : HOPE 計画策定を契機として組織されたまちづく り活動組織の継続性と評価, 日本建築学会計画系論文集, №. 608, pp. 97-102, 2006. 10

11) 屋外広告物ガイドライン〜仲通り周辺エリア編〜：大手町・丸の内・有楽 町地区まちづくり慇談会, 2014.10 


\title{
A STUDY OF REALITIES IN THE AREA MANAGEMENT BY URBAN RENEWAL CORPORATIONS
}

Focusing on the securing business continuity and the using urban renewal corporation system

\section{Takanori ITO * Ryo OYACHI** and Kohei MIYAKE**}

\author{
* Assoc. Prof., Graduate School of Engineering, Nagoya Institute of Technology, Ph.D.(design) \\ ** Master Course Student, Graduate School of Engineering, Nagoya Institute of Technology, Bachelor of Engineering
}

In the central city area, as city function transferring to the suburbs, declining of city function and increasing of vacant store are continuously proceeding.Thus, the activation of the central city area is planned for realization of 'the compact city' .

The private organizations such as private enterprise or rightful claimant of the ground are carrying out the area management, by means of city environment maintenance and events which generates activeness.

Meanwhile, 'Urban Renewal Corporation' system which includes deregulation of business running in public spaces such as road, was created. For that reason, it is expected to secure steady profit to private organizations appointed by 'Urban Renewal Corporation' , by running business actively in the public spaces,However, many organizations are facing problems in securing business profit.

The objective of this research is to grasp reality of area managements that operated by 'Urban Renewal Corporations' .

Realities in the running, securing continuity and utilizing 'Urban Renewal Corporation' system on operated businesses was surveyed. The results are as follows.

Table 3 and Figure 4 show the results of realities in running business. There were 2 types of organization; 1. Which mainly operates 'event' businesses 2 . Which mainly operates 'private facilities used' businesses.

Figure 5 and 6 show the results of realities in the securing business continuity. There were 2 types of organization; 1 . Which secures profit by operating businesses 2 . Which relies on subsidy.

Figure 7 and Table 6 show the results of realities in the utilizing 'Urban Renewal Corporation' system. There were 2 types of organization. 1. Which utilizes multiple systems 2 . Which does not utilize system.

It is necessary to use 'Urban Renewal Corporation' system on profit businesses, to maintain business continuity on area management operated by 'Urban Renewal Corporation' . 